\title{
Deep Engagement in Online Learning: Is it Possible?
} Carolyn Mamchur and Marco Espinoza

\begin{abstract} experience.

Carolyn Mamchur

Professor, Faculty of Education

Simon Fraser University

Mamchur@sfu.ca

Marco Espinoza

PhD candidate, Faculty of Education

Simon Fraser University

maespino@sfu.ca
\end{abstract}

This investigation is concerned with student 'engagement' in online learning. For the purpose of this study, the concept of 'engagement' is defined as 'meaningful participation'. While 'participation' can be demonstrated through quantifiable means, it is far more arduous to demonstrate 'meaningfulness'. To overcome this challenge, the study focused on specific forms of locutions, using the methodology of 'language-game' analysis. This form of analysis is epistemologically grounded on two theoretical traditions: Philosophy of Language and hermeneutic-phenomenology. The primary research objective of this investigation was to examine all aspects of the languagegames, see what is most prominent, what is least prominent, determine where this occurs, and suggest where the course might be improved. The study found that the highest level of activity were interactions that drew on readings and personal 


\section{Designing the Course}

When I was invited by the director of online course development at Simon Fraser University to revise an existing course on Classroom Management, I was apprehensive. I deeply disliked the title of the course and though the contents comprised an excellent survey of leading theories about classroom management, it was not seen as actually helping student and practicing teachers manage their classrooms. I attempted to change the nature of the assignments to more practice based, but a trial run proved more was needed. I decided to start over.

I abandoned the notion of a survey course, which would have been a good introduction for those wanting a graduate degree, but held little practical value for teachers facing a classroom of 40 students on a Monday morning. I turned, instead, to my own experience of a classroom teacher, as a teacher therapist in a school for 'wayward' girls and as a professor developing and teaching programs for pre and in service teachers.

What really mattered in the classroom? What, in my lived experience, made a classroom of people work with one another, with me, with the subject? What offered opportunity for meaningful engagement? And if I could come up with the factors that mattered most, could I create an online, undergraduate 3 credit course that would give students in a large class the opportunity to be, themselves, engaged in the process of learning? Would the course reflect the beliefs and values espoused by my selection? Was there enough time in a 3 credit course? Was there enough opportunity in a class of 45 students? Would a tutor marker be able to assist the students in the way I imagined as I created the course?

These questions haunted me as I began the painful process of selecting and discarding. I resisted the temptation to turn to the experts, the theorists, the researchers, as I worked. I wanted to keep to my own experiences, my own instincts. I wanted my voice in the course. I would turn to the experts when I selected the readings, but not now.

Careful reflection resulted in what I considered to be bare bones essentials necessary for successful engagement: Creating meaningful relationships, doing worthy work, learning in a safe environment and practicing fair and instructive evaluation processes.

Once I had my bones, I needed to bring the skeleton to life, to create assignments that would engage students in a way which went beyond proving they had understood the readings typically attached to such a course. Again, I resisted the temptation to go to the experts at this point and select readings for the course reader. I wasn't ready for that yet. I wanted to have the readings enrich and support the assignments, not the assignments grow out of the readings.

Finally, I decided upon a constructivist model designed to guide students through a process that encourages teachers to create meaningful and respectful relationships with students. That became the most important aspect of the whole course. To enable teachers to have the skills and attitudes necessary to create meaningful relationships, the course examined self and models of self awareness and self control, learning style 
theory, the importance of doing worthy work together: work that is worthy of the people doing it and that can be accomplished successfully in the time frame available. The course also illustrated and invited them to create, in the course they were experiencing, an environment that was a safe and comfortable space in which students and teachers with common goals can work successfully together. The course by way of example and reflection and transparency on what and why I was asking for, would also hopefully, teach methods of evaluation that were fair and promoted learning.

It was not a course about specific traditional techniques on classroom management, but rather a course that focused on attitudes, perceptions, all around fairness, relevancy, respect. It was designed to teach how to be with the 'other'. For such a course to function, I recognized the importance of an ontological approach as Buber (2000) describes it, using dialogue as a way of life. Peer interactions were crucial to the process.

Because peer interactions were such a crucial element in the course, I was eager to investigate the nature of this form of student engagement. An opportunity presented itself when Simon Fraser's new president offered small grants to examine teaching practice as a means of encouraging of culture that valued teaching as much as research.

Marco Espinoza, doctoral candidate who had been working with me as tutor marker for the course had an unique approach to analyzing the peer interactions. He was using a system to examine reflexivity that seemed most appropriate for our purposes.

\section{The Study}

The investigation was essentially concerned with student 'engagement' in online learning, an area of grounding importance in this course in particular. Meaningful engagement, as opposed to the mere exchange of information, has become a focus of research on online learning (Bound, 2010; Paulus\& Scherff, 2008; Lowerison, Sclater, Schmid \& Abrami, 2006; Fisher, Thompson \& Silverberg, 2005; Rose, 2004; Webb, Jones, Barker \& van Schaik, 2004). For the purpose of our study, the concept of 'engagement' was defined as 'meaningful participation'. While 'participation' can be demonstrated through quantifiable means, it is far more arduous to demonstrate 'meaningfulness'. For instance, when the 'meaningfulness' of peer interaction is determined by the personal judgment of participants, the spectrum of results can be too broad, rendering findings inconclusive. Analyzing the actual text of student interactions in an online course is a research approach that can be helpful in teasing out the nuances of what students are saying to one another (Zembylas, 2008; Dennen \& Wieland, 2007; Ziegler, Paulus \& Woodside, 2006; Sorensen, Takle \& Moser, 2006). This investigation focused on specific forms of locutions, using the methodology of 'language-game' analysis. This form of analysis is epistemologically grounded on two theoretical traditions: Philosophy of Language and hermeneutic-phenomenology (Austin, 1962; Merleau-Ponty, 1962, 1968; Wittgenstein, 1958). The primary research objective of this investigation was to examine all aspects of the language-games, see what is most prominent, what is least prominent, determine where this occurs, and suggest where the course might be improved. 
Language-game analysis is a highly contextualized method of investigation. It requires a keen sensitivity to nuances in language expression. It also requires judgments to be made when distinguishing one language-game from another. In this study, to achieve a high level of discriminatory reading, the interaction text needed numerous rereadings and comparison between peer statements in order to identify the locutionary intentions of language-games as they began to emerge. Language-game analysis also requires a clear understanding of the dialogic frame in which the interactions of subjects have taken place.

The course asked students to complete reading tasks, peer interaction tasks, progress $\log$ tasks and a major assignment. Peer interaction tasks were worth $15 \%$ of the final grade and were described in the introduction as, "You are expected to send ideas and thoughts to your peers online. At times, you will be invited to comment on one another's ideas." It was the peer interaction tasks that were analyzed in this study.

The study subjects were ten students who had completed the course between 2009 and 2010: two of the subjects completed the course in the fall semester of 2009; the remainder completed it in 2010, with three in the spring, three in the summer and two in the fall. The background of the subjects was consistent with the demographics of students who take this course. Course demographics range from undergrad students to senior teachers. Most undergrad students who take this course express that they wish to apply to SFU's Professional Development Program (PDP) to become certified teachers. In addition, some students are already in PDP, while others have recently obtained their teacher certification. There are a few who are practicing teachers: some are just starting their careers, while others are at the point of retirement. Moreover, there is a lesser group of students who are completing their undergrad studies and take this course as an elective.

The study identified nine predominant language-games. Each language-game has been given a name that describes its locutionary intention. The following is a list of the nine language-games with descriptions of their locutionary intentions, and examples taken from the study.

* The language-game of Peer Acknowledgement has an inclusive tone. The intention is to recognize peer contributions to the online discussion. For example:

- "I love reading all of your stories and appreciate so much that you share them. It truly shows how powerful narratives can be!" (subject E, week 5).

- "Wow, Motown singing. I wish I could hear you sing. I am always in awe of people who have the voice and confidence to sing. It is so fantastic. Thanks for sharing" (subject H, week 2).

- "you and I could team teach. We both have the same ideas about order and what makes a classroom run smoothly" (subject B, week 4, task 2). 
* The language-game of Peer Engagement also has an inclusive tone. The intention is to encourage peers to participate. For example:

- "Do you gals think that women tend more to be the feelers and men the thinkers in general? Of course there are bound to be different types within the sexes.... Do you think it would be genetics or upbringing that would be the biggest influence?" (subject G, week 4, task 1).

- "Another question Introverts: I am wondering in what ways do you prefer to be praised or rewarded for a job well done?” (subject F, week 3, task 2).

- “Does anyone else have this experience?” (subject I, week 10).

* The language-game of Logically Thinking Through has an inquiry tone. The intention is to reason through ideas, unpack information, seek understanding. For example:

- "I am very interested in personality types for teaching and as a TOC always take note of the students that do speak up and the ones that are more quiet. I have always felt that partipation marks in a class should be more suited to both types: that is the extroverts are comfortable speaking out, but it tends to put the introverts at a disadvatage, so perhpas journaling would be another way a teacher could gather partipation marks? that way more personality types are having their needs met?" (subject A, week 3, task 2).

- "I am beginning to wonder if I am a little "old school" if you know what I mean. I just can't fly by the seat of my pants on anything in school; especially the school I teach in.. that is rigid and very traditional in it's atmosphere. I think your surroundings and environment can change you ideas about school words, when you have the pressure of conformity" (subject B, week 4, task 2).

- "I believe teachers need to be a combination of both, that is, a teacher cannot be overly analytical and not overly empathetic. While some may argue that being objective is more important, I do not agree. First of all, according to the textbook definition, a thinker tends to stand back, follows the rules, and tries to be fair. However, teachers need to connect with their students to create an open and friendly environment. Moreover, the rules cannot always apply, and nothing in life is truly fair; in fact, sometimes in order to be fair, rules must be broken. Lastly, rules may allow you to do what is logical, but not necessarily what is right." (subject C, week 4, task 1). 
* The language-game of Reporting has a matter-of-fact tone. The intention is to provide information with little attention to offering insight or soliciting interaction. For example:

- "In the grade 1 classroom that I volunteer in, I found that when the teacher asked a question during circle time, both boys and girls called out of turn equally. However, during all other classroom lessons, it was more often that the boys were calling out and being off task. This meant that the boys were also more likely to receive the teachers attention (whether positive or negative)" (subject E, week 10, assignment $3)$.

- "As an extravert teacher, the strategies that I would use in the classroom are: -An open classroom atmosphere with opportunity for talk and discussion. -Projects involving group work and hands on activities like science labs and art work. -Create a space in the classroom for big projects allowing noise, peer interaction, physical movement” (subject H, week 3, task 2).

- "I have observed seating arrangements in both the grade five class and the kindergarten class that I am volunteering in. In the grade five class, their arrangement is changed weekly but is always in the same formation of two's and three's. Every week the teacher makes new arrangements for the students. Usually it is arranged as one week separated by gender followed by the next week with mixed gender seating. Each time, however, there is variation of who sits next to whom" (subject D, week11).

* The language-game of Personal Insight has a sincere tone. The intention is to express honest views and feelings.

- "I was open and honest with the students and talked about growing up with addiction, and loosing my Mum to her addiction. I explained that running was the way I saved myself as a kid. I ran and ran, and eventually I was good at it. But I ran to deal with what was going on at home. It was a hard talk to do, as not that long ago my Mum had died. The students were amazing. quiet and attentive and had thoughtful questions. It made me realize that being honest with them and sharing part of my life, made that meaningful relationship with each and every one of them" (subject A, week 5).

- "Personally, I like to do my work without someone hovering over my shoulder, which is true for my type preference as an introvert. I do not feel comfortable under constant supervision and, in most cases, I achieve at higher levels when I am left to my own prerogative" (subject C, week 4.2).

- "I've always rooted for the underdog and I know they need more from a teacher, not less. Relationships are so important! I just took part in a Facebook discussion in which a relative of mine said that a teacher doesn't have to like their students, their job is to teach. I was livid! HELLLOOOO! You can't teach them if they don't like you or they know you don't like them...the relationship is key. I just have to shake my 
head when I'm told that a Grade 4 student needs to start taking his work more seriously as his marks are suffering... I don't think a Grade 4 kiddo is thinking, wow, if I don't do well on this math test I may not get into the college of my choice...they're thinking, school is torture and I don't want to be here" (subject G, week 5).

* The language-game of Critical Self-Awareness is an expression of realization about one's own actions and thoughts as a result of interacting in one of the peer discussion.

- "This point just made me reflect further that I will need to sometimes take a second look at how I run the classroom and let it go for the sake of chaos and freedom once in a while too as I am also heavy on the Judgment side" (subject H, week 4, task 2).

- "I've never really thought about the fact that my creative, ever-changing, energized, etc. classroom was counter-productive and overwhelming for my introverted learners" (subject I, week 3, task 2).

- "I just thought it was interesting that I was using type theory (in a way) before I even knew what it was. I also think it is interesting that, being very very evenly split between being a thinking and feeling type, I have an even assortment of thinking and feeling friends. These differences are usually important to me when I run into a conflict. I need both types of friends to help me through it" (subject E, week 4, task 1).

* The language-game of Recapitulation has a narrator's tone. The intention is to provide 'summary' or 'explanatory' statements, possibly identify 'universals'; but in trying to help clarify the discussion for peers, may come across a bit opinionated or patronizing.

- "[first peer], you started to encourage and support your honey's vision to be in better shape and he responded favourably and was grateful for it. [second peer], you and your friend re-scheduled time together and communicated about the miscommunication. [third peer] - bless your heart as well - you went above and beyond (in my opinion) and covered shifts no questions asked. In these situations, I see that complete restitution had been made. In [fourth peer] case - there is a moment in time, a piece of the relationship that can never be recovered. In [fifth peer] case, her brother will never be able to get that moment back because years have gone by" (subject I, week 10).

- Responding to a peer's post about a memorable teacher: "I can see how meaningful that would be! Especially to have her remember for so long. She must have really listened to everything all of her students had to say. These stories created individuals out of all of her students, like yourself. I guess this is what we're all learning to do with our future classrooms - make meaningful relationships!” (subject E, week 5).

- Responding to a peer's post: "Balancing mind, body and spirit is certainly essential for any healthy vibrant person and you recognized that for yourself! Bravo for seizing 
the moment of stillness which presented itself. I noticed too you are very reflective and conscious of the import of keeping a rounded life-style, not all work and no play/enjoyment, such a key aspect to keeping oneself balanced” (subject F, week 2).

* The language-game of Experienced Practitioner has an authoritative tone. The intention is to offer insight from the point of view of an experience teacher.

- "Often it is possible to allow students to choose who they will sit with while being able to influence where. I have some students who need to sit near me due to behavioural issues, but they still have input into who sits with them. One thing I noticed that was absent from the article was any reference to wheelchairs. Since there are many students with physical disabilities in classrooms now, it is important to address them and their seating needs. They require more space for their desk and the area surrounding it and this may influence the overall desk arrangements for the classroom" (subject J, week 11).

- "I am finding that the classes that have used the smart board have missed a few written skills. (complete sentences, periods, capitals, and general neat printing skills) But it is an amazing tool if used in a balanced sort of way. Alberta classrooms have many of these, and have had them for some time....unfortunately some are sitting idle for many reasons. I am sad to say the novelty has passed in some Alberta boards, and the smart boards are turned off most of the time!" (subject B, week 10.3).

* The language-game of Utility seeks clarification on assignments.

- "I am in the introvert group. I am not sure how we put ourselves into groups? Has anyone done on-line before and if so, do you know how to do this?" (subject A, week 3, task 2).

- "I am having trouble with my new PDF Broadgun program. Sorry everyone! I will attach in good old WORD!" (subject B, week 4, task 2).

- "under Announcements, posted May 11th, there is a list of all the assignment due dates and it shows these 2 peer interaction tasks and our week $10 \mathrm{log}$, but assignment 3 due next week like you say...hope this helps :)" (subject G, week 10, assignment 3).

To determine how often each language-game occurred, two methods were used, word count and subject participation. First, based on word count, the highest occurring was Personal Insight with fifty percent of all words exchanged by subjects in their peer interactions. The language-game Logically Thinking Through was next, accounting for fifteen percent, followed by Peer Acknowledgement, responsible for eleven percent. (see Graph 1). 
Graph 1

Peer Interaction Language Games (based on $\%$ of total word-count ${ }^{1}$ )

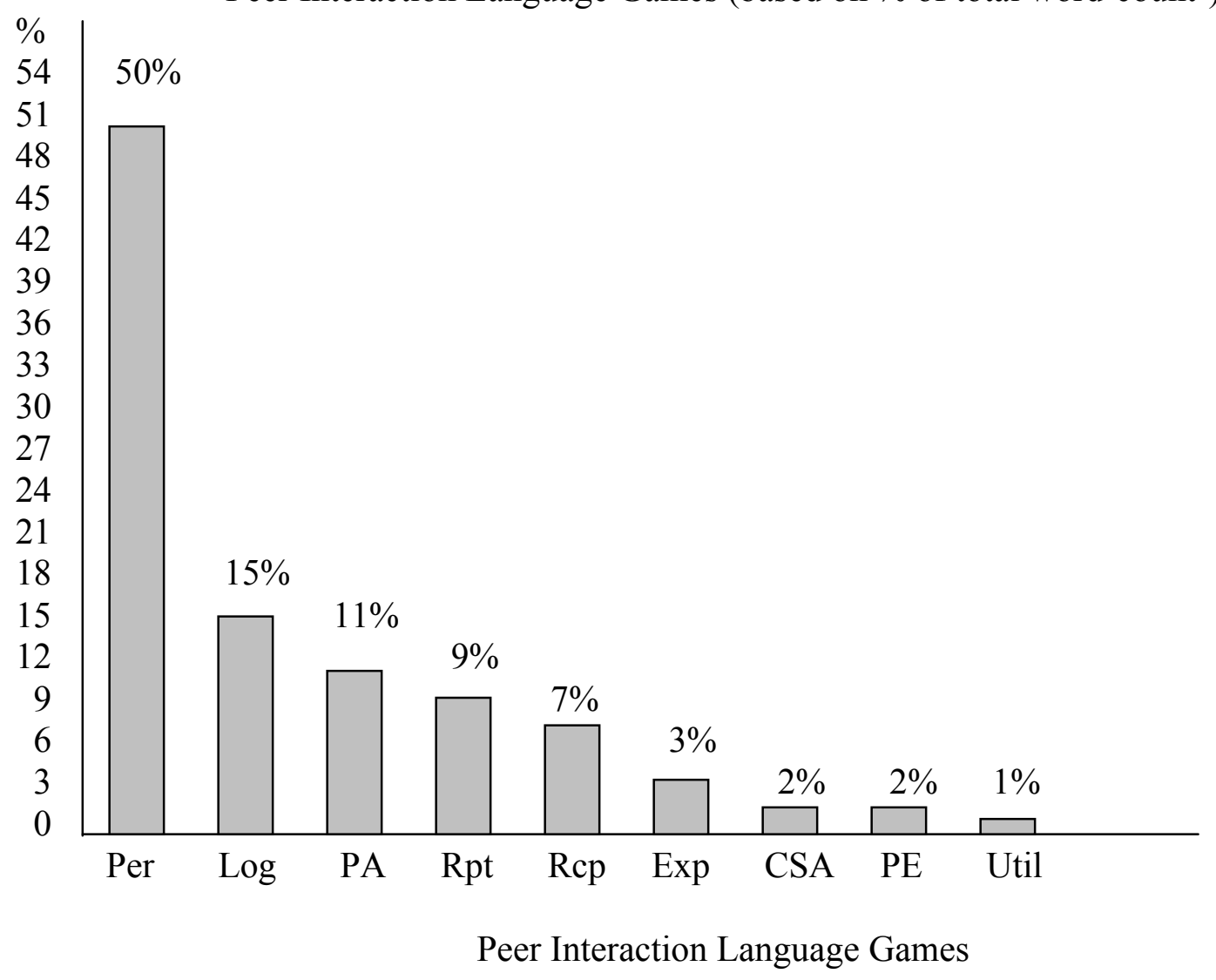

${ }^{1}$ Word-count is based on initial posts by subjects and their responses to non-subject peers, but does not include non-subject responses to the study-subjects.

\begin{tabular}{|l|}
\hline KEY FOR GRAPH 1 \\
Per = Personal Insight \\
Log = Logically Thinking Through \\
PA = Peer Acknowledgement \\
Rpt = Reporting \\
Rcp = Recapitulation \\
Exp = Experienced Practitioner \\
CSA = Critical Self-Awareness \\
PE = Peer Engagement \\
Util = Utility
\end{tabular}


Second, based on subject participation in each language-game, Personal Insight again topped the list, accounted for seventy-nine out of a possible one hundred times, the same as Peer Acknowledgement. Logically Thinking Through was next with participation of thirty-nine times (see Graph 2). In addition, when looking at participation on a weekly basis, these three language-games were dominant throughout the course (see Graph 3). There were some slight changes when weekly activity was based on word count; nonetheless, Personal Insight remained the dominant languagegame (see Graph 4).

Graph 2

Participation Per Language Game ${ }^{1}$

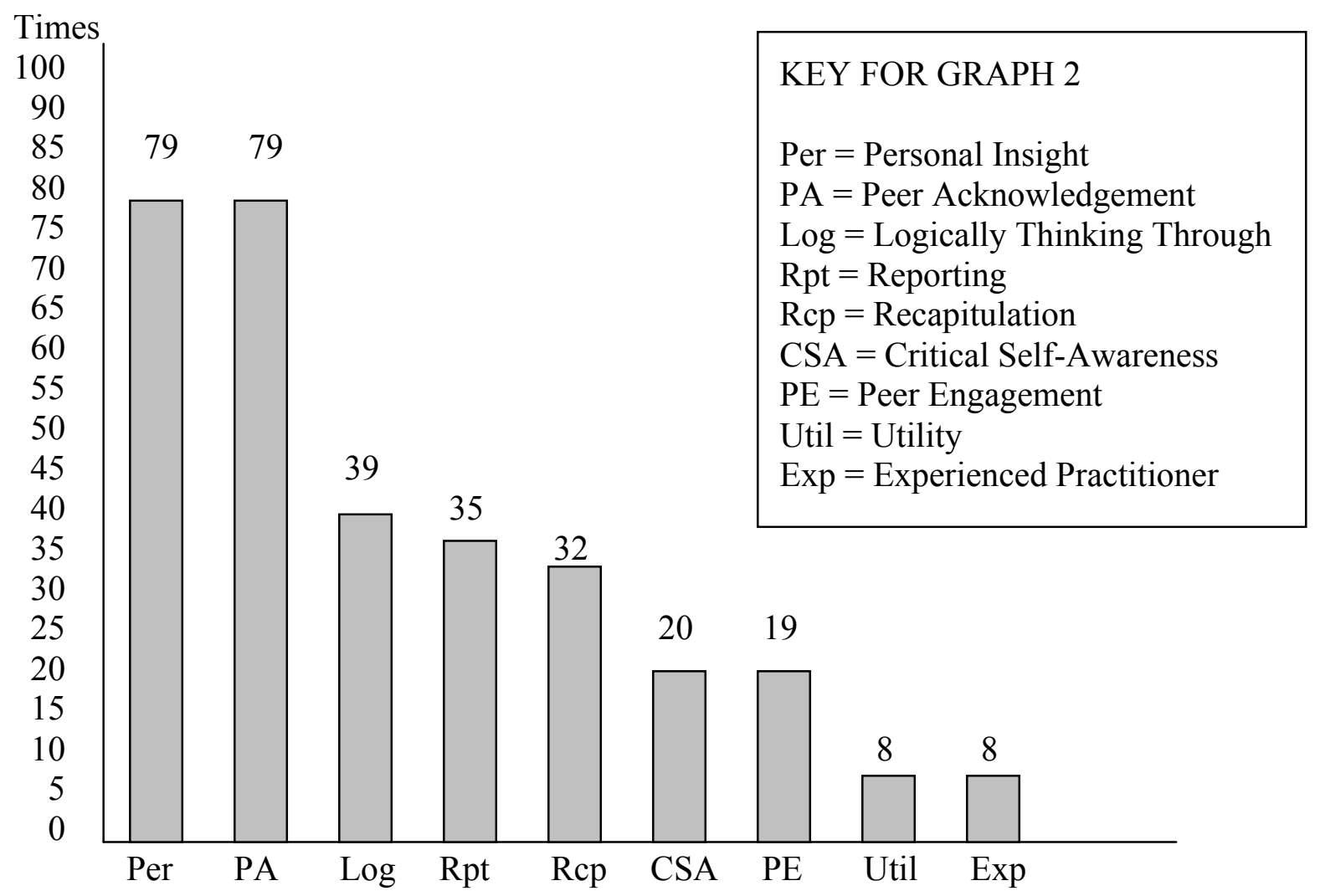

Peer Interaction Language Games

${ }^{1}$ Participation is based on the number of subjects who participated in each language-game in the Peer Interactions (max. 10 subjects $\times 10$ interaction activities $=100$ times). 
Graph 3

Peer Interactions: most active Language Games (based on participation ${ }^{1}$ )

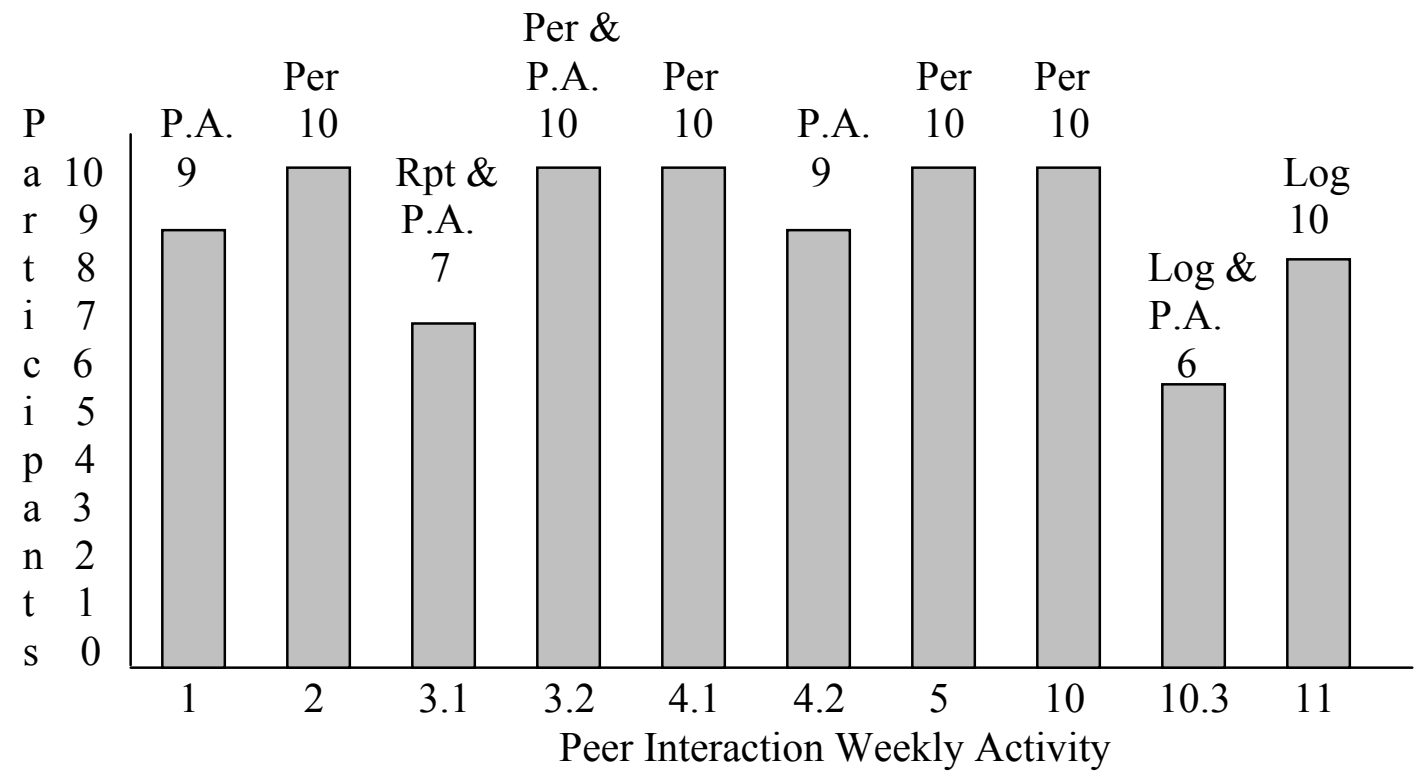

${ }^{1}$ Participation is based on the number of subjects who participated in each language-game in each Peer Interactions (max. 10 per weekly activity).

\begin{tabular}{|l|l|}
\hline KEY FOR GRAPH 3 & Exp = Experienced Practitioner \\
\hline Per = Personal Insight & CSA = Critical Self-Awareness \\
Log = Logically Thinking Through & PE = Peer Engagement \\
PA = Peer Acknowledgement & Util = Utility \\
Rpt $=$ Reporting & \\
Rcp = Recapitulation & \\
\hline
\end{tabular}

\begin{tabular}{|l|l|}
\hline Week & Peer Interaction Descriptor \\
\hline 1 & Please post a message of introduction to your fellow group members. \\
\hline 2 & Go out and do something that makes you feel good \\
\hline 3.1 & Determine your own type preferences. \\
\hline 3.2 & Introvert/extrovert discussion \\
\hline 4.1 & Type differences "thinking, feeling "story \\
\hline 4.2 & Respond to these "school" words: schedule, punctuality, order, rules, supervision \\
\hline 5 & Meaningful relationship short narrative \\
\hline 10 & A time when you "wronged" someone, restitution. \\
\hline 10.3 & Observation on Gender Equity in the Classroom \\
\hline 11 & Would you permit students to sit where they want in your classroom? \\
\hline
\end{tabular}


Graph 4

Peer Interactions: most active Language Games (based on $\%$ of total word count ${ }^{1}$ )

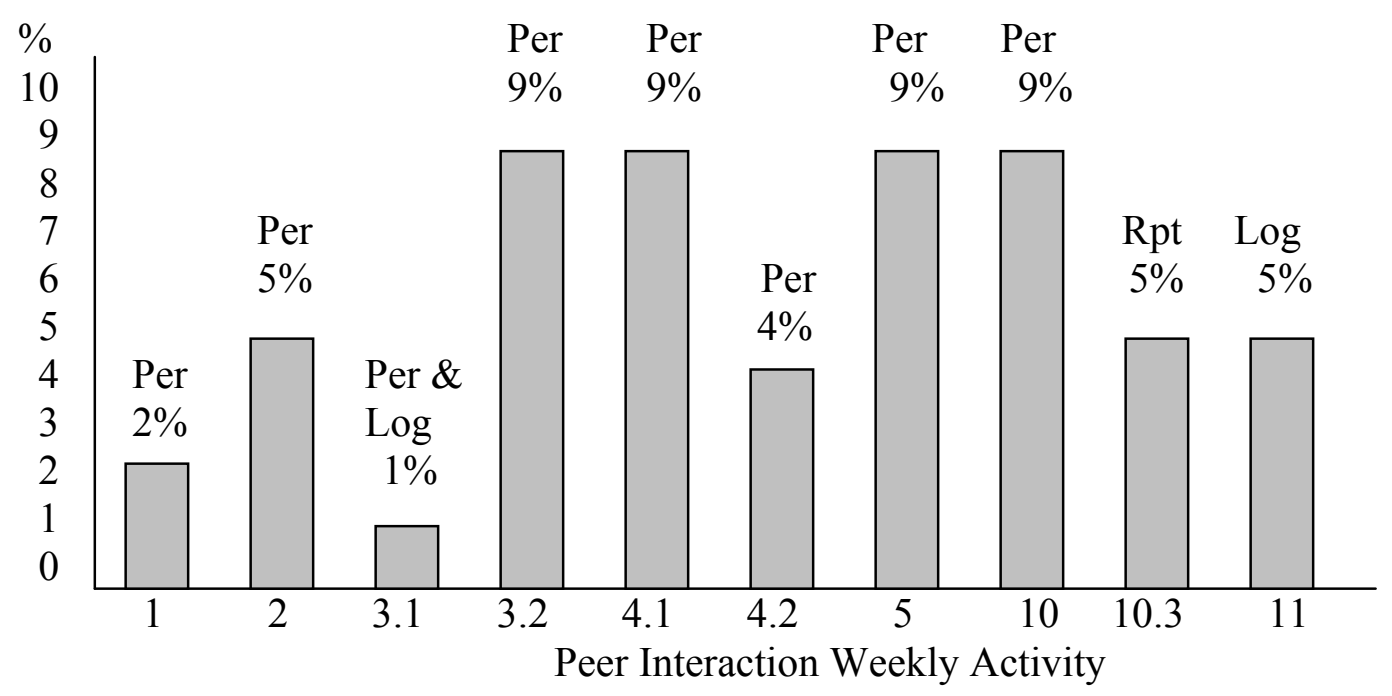

${ }^{1}$ Word-count is based on initial posts by subjects and their responses to non-subject peers, but does not include responses by non-subject peers to the subjects.

\begin{tabular}{|l|l|}
\hline KEY FOR GRAPH 4 & Exp = Experienced Practitioner \\
\hline Per $=$ Personal Insight & CSA = Critical Self-Awareness \\
Log = Logically Thinking Through & PE = Peer Engagement \\
PA = Peer Acknowledgement & Util = Utility \\
Rpt $=$ Reporting & \\
Rcp $=$ Recapitulation & \\
\hline
\end{tabular}

\begin{tabular}{|l|l|}
\hline Week & Peer Interaction Descriptor \\
\hline 1 & Please post a message of introduction to your fellow group members. \\
\hline 2 & Go out and do something that makes you feel good \\
\hline 3.1 & Determine your own type preferences. \\
\hline 3.2 & Introvert/extrovert discussion \\
\hline 4.1 & Type differences "thinking, feeling "story \\
\hline 4.2 & Respond to these "school" words: schedule, punctuality, order, rules, supervision \\
\hline 5 & Meaningful relationship short narrative \\
\hline 10 & A time when you "wronged" someone, restitution. \\
\hline 10.3 & Observation on Gender Equity in the Classroom \\
\hline 11 & Would you permit students to sit where they want in your classroom? \\
\hline
\end{tabular}

When looking at the most common occurrence of each language-game per peer interaction, the frequency of language-games was for the most part consistent whether measured by word count or participation. 
The study identified other notable findings. The most active peer interaction assignments were weeks three (task two), four (task one), five and eleven; the two least active were weeks one and three (task one) (see Graphs 5 and 6).

Graph 5

Peer Interaction Weekly Activity (based on $\%$ of total word count ${ }^{1}$ )

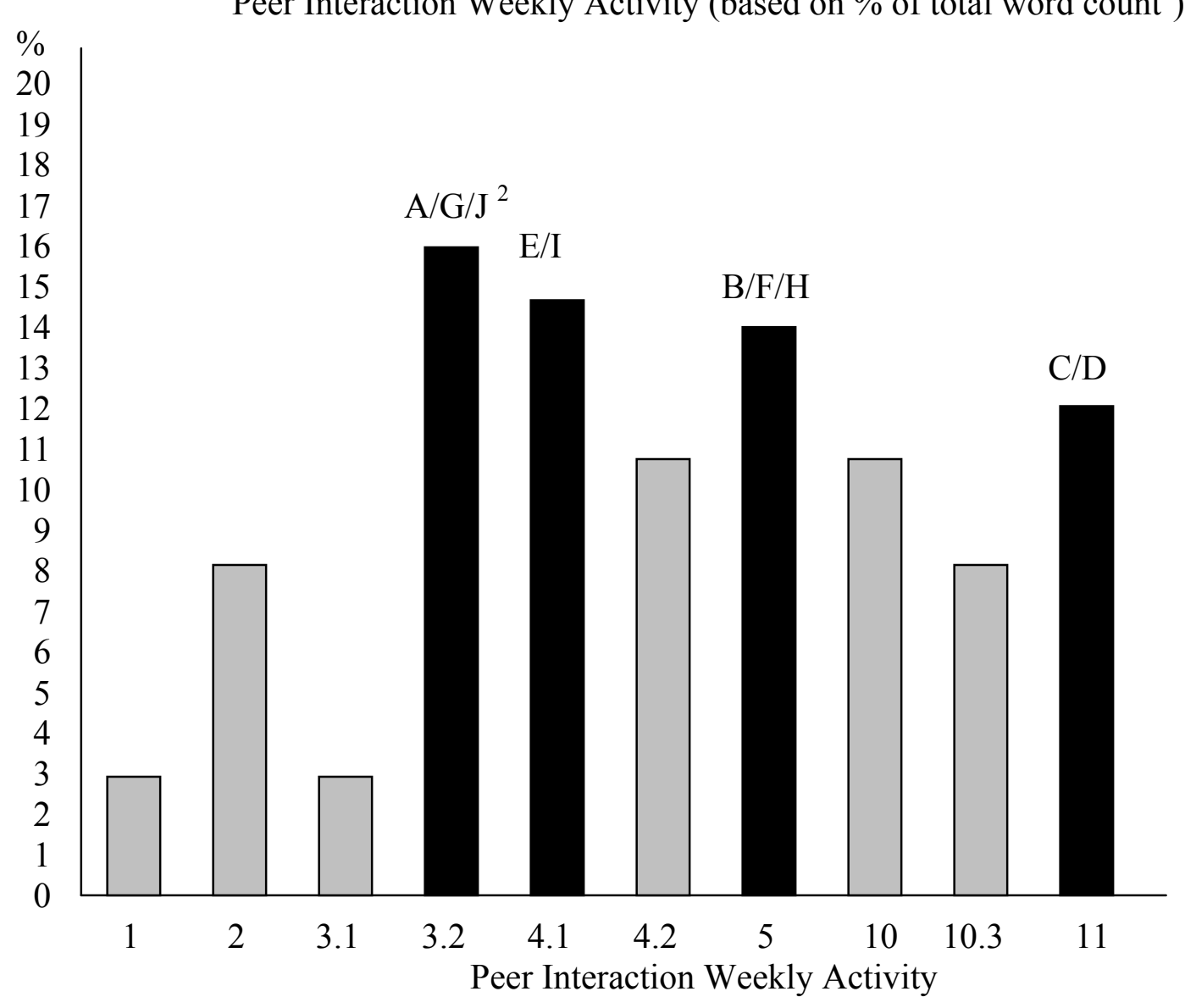

\begin{tabular}{|c|c|c|c|c|c|c|c|c|c|c|}
\hline Subject & \multicolumn{9}{|c|}{ Peer Interactions from most active to least (with \% of each student-subject's word count) } \\
\hline A & $3.2(25)$ & $11(18)$ & $4.2(13)$ & $4.1(10)$ & $5(10)$ & $10(8)$ & $2(6)$ & $10.3(4)$ & $1(3)$ & $3.1(3)$ \\
\hline B & $5(16)$ & $4.1(15)$ & $4.2(14)$ & $2(13)$ & $11(12)$ & $3.2(10)$ & $10(10)$ & $3.1(4)$ & $1(3)$ & $10.3(3)$ \\
\hline C & $11(14)$ & $4.1(13)$ & $10(13)$ & $10.3(12)$ & $3.2(11)$ & $4.2(11)$ & $2(10)$ & $5(8)$ & $3.1(7)$ & $1(2)$ \\
\hline D & $11(17)$ & $3.2(14)$ & $5(14)$ & $10.3(13)$ & $4.2(11)$ & $10(11)$ & $4.1(10)$ & $2(8)$ & $1(2)$ & $3.1(1)$ \\
\hline E & $4.1(18)$ & $3.2(16)$ & $4.2(15)$ & $5(14)$ & $10(14)$ & $2(9)$ & $10.3(7)$ & $11(4)$ & $1(2)$ & $3.1(1)$ \\
\hline F & $5(22)$ & $11(16)$ & $3.2(15)$ & $2(14)$ & $4.1(8)$ & $10.3(7)$ & $1(6)$ & $10(6)$ & $4.2(5)$ & $3.1(1)$ \\
\hline G & $3.2(21)$ & $4.2(19)$ & $10.3(17)$ & $5(14)$ & $10(8)$ & $4.1(7)$ & $3.1(4)$ & $11(4)$ & $1(3)$ & $2(2)$ \\
\hline H & $5(18)$ & $4.1(16)$ & $3.2(12)$ & $10.3(12)$ & $4.2(11)$ & $11(10)$ & $2(9)$ & $10(9)$ & $1(3)$ & $3.1(1)$ \\
\hline I & $4.1(32)$ & $10(20)$ & $3.2(18)$ & $5(10)$ & $11(9)$ & $4.2(4)$ & $2(3)$ & $10.3(3)$ & $1(1)$ & $3.1(0)$ \\
\hline J & $3.2(23)$ & $11(18)$ & $5(17)$ & $10(15)$ & $4.1(10)$ & $10.3(9)$ & $2(3)$ & $1(2)$ & $3.1(1)$ & $4.2(1)$ \\
\hline
\end{tabular}

${ }^{1}$ Word count is based on initial posts by subjects and their responses to non-subject peers, but does not include non-subject students' responses to the study subjects.

${ }^{2}$ the ten subjects are identified by letters A to J. 
Graph 6

Peer Interaction Weekly Activity (based on \% of total amount of interactions ${ }^{1}$ )

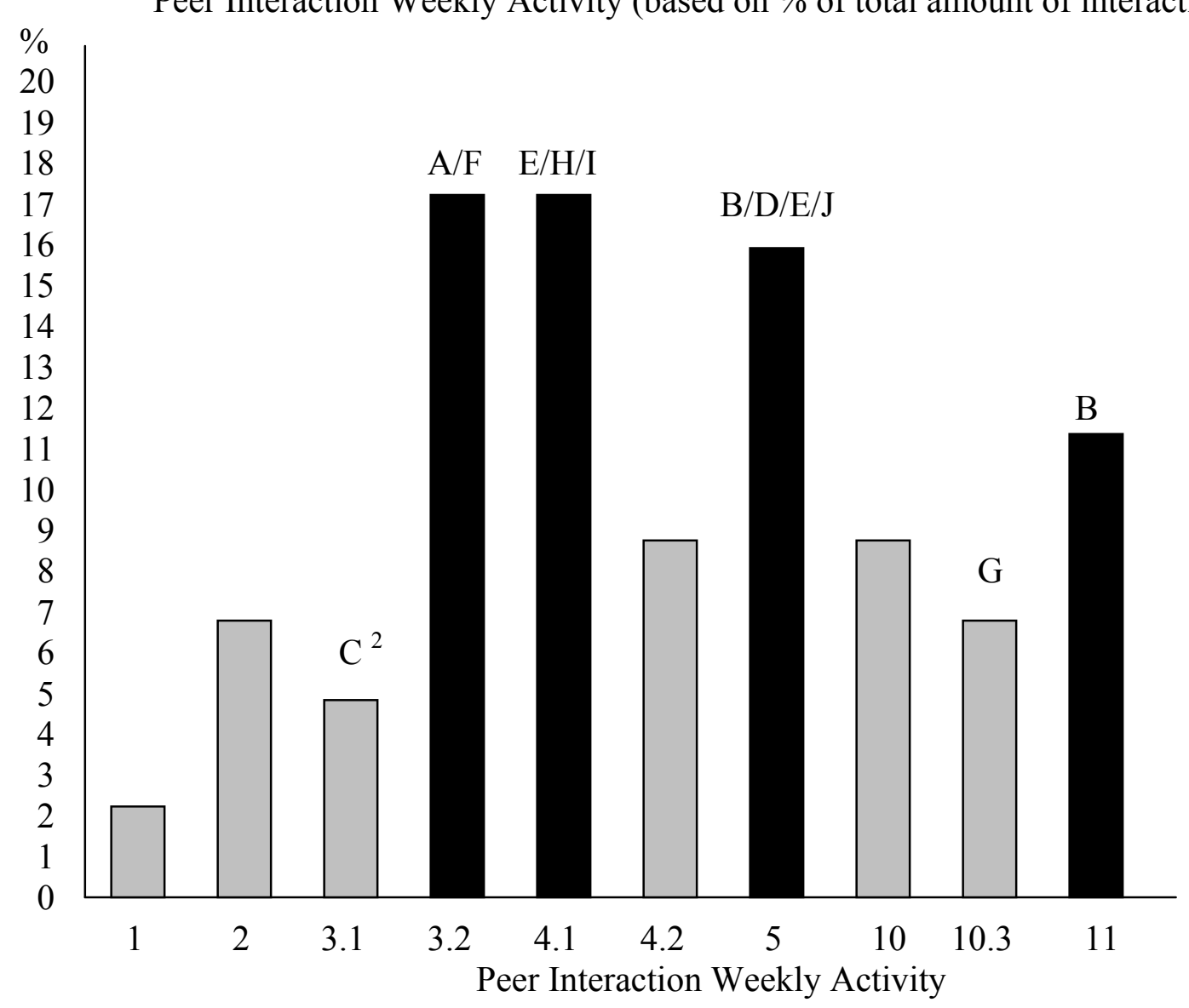

\begin{tabular}{|c|l|l|l|l|l|l|l|l|l|l|}
\hline Subject & \multicolumn{6}{|c|}{ Peer Interactions from most active to least (\& amount of each student-subject's interactions) } \\
\hline A & $3.2(9)$ & $11(8)$ & $4.2(3)$ & $2(2)$ & $10.3(2)$ & $1(1)$ & $3.1(1)$ & $4.1(1)$ & $5(1)$ & $10(1)$ \\
\hline B & $5(14)$ & $11(14)$ & $4.1(10)$ & $10(10)$ & $3.2(9)$ & $4.2(8)$ & $2(7)$ & $3.1(6)$ & $1(4)$ & $10.3(1)$ \\
\hline C & $3.1(6)$ & $4.1(5)$ & $3.2(4)$ & $11(4)$ & $5(3)$ & $1(2)$ & $2(2)$ & $4.2(2)$ & $10(2)$ & $10.3(2)$ \\
\hline D & $5(4)$ & $4.1(3)$ & $3.2(2)$ & $4.2(2)$ & $10.3(2)$ & $10(1)$ & $11(1)$ & $1(0)$ & $2(0)$ & $3.1(0)$ \\
\hline E & $4.1(6)$ & $5(6)$ & $3.2(3)$ & $4.2(3)$ & $10(2)$ & $10.3(2)$ & $2(1)$ & $1(0)$ & $3.1(0)$ & $11(0)$ \\
\hline F & $3.2(8)$ & $2(6)$ & $5(3)$ & $10(2)$ & $4.2(1)$ & $10.3(1)$ & $1(0)$ & $3.1(0)$ & $4.1(0)$ & $11(0)$ \\
\hline G & $10.3(6)$ & $4.2(5)$ & $3.2(4)$ & $4.1(3)$ & $11(2)$ & $3.1(1)$ & $5(1)$ & $1(0)$ & $2(0)$ & $10(0)$ \\
\hline H & $4.1(12)$ & $5(6)$ & $10.3(6)$ & $3.2(5)$ & $2(4)$ & $11(3)$ & $4.2(1)$ & $10(1)$ & $1(0)$ & $3.1(0)$ \\
\hline I & $4.1(8)$ & $10(7)$ & $5(5)$ & $3.2(4)$ & $4.2(1)$ & $1(0)$ & $2(0)$ & $3.1(0)$ & $10.3(0)$ & $11(0)$ \\
\hline J & $5(6)$ & $4.1(5)$ & $3.2(3)$ & $10(1)$ & $1(0)$ & $2(0)$ & $3.1(0)$ & $4.2(0)$ & $10.3(0)$ & $11(0)$ \\
\hline
\end{tabular}

the amount of interactions is based on number of times others respond to a student-subject's initial post, as well as the number of times a student-subject responds to others.

${ }^{2}$ the ten subjects are identified by letters A to $\mathrm{J}$ 
In addition, the highest level of activity was found in interactions that drew on readings and personal experience. In contrast, the least active interaction assignments drew on either personal experience or readings, but not both. It was inconclusive whether a written component (e.g., journal entry or short assignment) fostered or hindered interaction, because this component was absent half the time at both levels (see Tables 1a and $1 \mathrm{~b})$. 
Table 1a

\begin{tabular}{|c|c|c|c|c|c|c|c|c|c|c|}
\hline Subject & \multicolumn{10}{|c|}{ Peer Interactions from most active to least (with \% of each student's word count) } \\
\hline A & $3.2(25)$ & $11(18)$ & $4.2(13)$ & $4.1(10)$ & $5(10)$ & $10(8)$ & $2(6)$ & $10.3(4)$ & $1(3)$ & $3.1(3)$ \\
\hline $\begin{array}{c}\text { Journal } \\
\text { Entry }\end{array}$ & $\bar{Y}$ & $\mathrm{~N}$ & $\begin{array}{c}\mathrm{N} \\
\text { Asgn.1 }\end{array}$ & $\begin{array}{c}\mathrm{Y} \\
\text { Asgn.1 }\end{array}$ & $\mathrm{N}$ & $\mathrm{Y}$ & $\bar{Y}$ & $\begin{array}{c}\mathrm{Y} \\
\text { Asgn.3 }\end{array}$ & $\mathrm{N}$ & $\mathrm{N}$ \\
\hline Activity & $\mathrm{R} / \mathrm{P}$ & $\mathrm{R} / \mathrm{P}$ & $\mathrm{P}$ & $\mathrm{R} / \mathrm{P}$ & $\mathrm{R} / \mathrm{P}$ & $\mathrm{P}$ & $\mathrm{P}$ & A & $\mathrm{P}$ & $\mathrm{R}$ \\
\hline $\mathrm{B}$ & $5(16)$ & $4.1(15)$ & $4.2(14)$ & $2(13)$ & $11(12)$ & $3.2(10)$ & $10(10)$ & $3.1(4)$ & 1(3) & $10.3(3)$ \\
\hline $\begin{array}{c}\text { Journal } \\
\text { Entry }\end{array}$ & $\mathrm{N}$ & $\begin{array}{c}\mathrm{Y} \\
\text { Asgn.1 }\end{array}$ & $\begin{array}{c}\mathrm{N} \\
\text { Asgn.1 }\end{array}$ & $\mathrm{Y}$ & $\mathrm{N}$ & $\mathrm{Y}$ & $\mathrm{Y}$ & $\mathrm{N}$ & $\mathrm{N}$ & $\begin{array}{c}\mathrm{Y} \\
\text { Asgn.3 } \\
\end{array}$ \\
\hline Activity & $\mathrm{R} / \mathrm{P}$ & $\mathrm{R} / \mathrm{P}$ & $\mathrm{P}$ & $P$ & $\mathrm{R} / \mathrm{P}$ & $\mathrm{R} / \mathrm{P}$ & $\mathrm{P}$ & $\mathrm{R}$ & $\mathrm{P}$ & A \\
\hline $\mathrm{C}$ & 11(14) & $4.1(13)$ & $10(13)$ & $10.3(12)$ & $3.2(11)$ & $4.2(11)$ & $2(10)$ & $5(8)$ & $3.1(7)$ & $1(2)$ \\
\hline $\begin{array}{c}\text { Journal } \\
\text { Entry }\end{array}$ & $\mathrm{N}$ & $\begin{array}{c}\mathrm{Y} \\
\text { Asgn.1 }\end{array}$ & $\mathrm{Y}$ & $\begin{array}{c}\mathrm{Y} \\
\text { Asgn.3 } \\
\end{array}$ & $\mathrm{Y}$ & $\begin{array}{c}\mathrm{N} \\
\text { Asgn.1 } \\
\end{array}$ & $\mathrm{Y}$ & $\mathrm{N}$ & $\mathrm{N}$ & $\mathrm{N}$ \\
\hline Activity & $\mathrm{R} / \mathrm{P}$ & $\mathrm{R} / \mathrm{P}$ & $\mathrm{P}$ & A & $\mathrm{R} / \mathrm{P}$ & $\mathrm{P}$ & $\mathrm{P}$ & $\mathrm{R} / \mathrm{P}$ & $\mathrm{R}$ & $\mathrm{P}$ \\
\hline $\mathrm{D}$ & $11(17)$ & $3.2(14)$ & $5(14)$ & $10.3(13)$ & $4.2(11)$ & $10(11)$ & $4.1(10)$ & $2(8)$ & $1(2)$ & $3.1(1)$ \\
\hline $\begin{array}{c}\text { Journal } \\
\text { Entry }\end{array}$ & $\mathrm{N}$ & $\mathrm{Y}$ & $\mathrm{N}$ & $\begin{array}{c}\mathrm{Y} \\
\text { Asgn.3 }\end{array}$ & $\begin{array}{c}\mathrm{N} \\
\text { Asgn.1 }\end{array}$ & $\mathrm{Y}$ & $\begin{array}{c}\mathrm{Y} \\
\text { Asgn.1 }\end{array}$ & $\mathrm{Y}$ & $\mathrm{N}$ & $\mathrm{N}$ \\
\hline Activity & $\mathrm{R} / \mathrm{P}$ & $\mathrm{R} / \mathrm{P}$ & $\mathrm{R} / \mathrm{P}$ & A & $\mathrm{P}$ & $\mathrm{P}$ & $\mathrm{R} / \mathrm{P}$ & $\mathrm{P}$ & $\mathrm{P}$ & $\mathrm{R}$ \\
\hline $\mathrm{E}$ & $4.1(18)$ & $3.2(16)$ & $4.2(15)$ & $5(14)$ & $10(14)$ & $2(9)$ & $10.3(7)$ & $11(4)$ & $1(2)$ & $3.1(1)$ \\
\hline $\begin{array}{c}\text { Journal } \\
\text { Entry }\end{array}$ & $\begin{array}{c}\mathrm{Y} \\
\text { Asgn.1 }\end{array}$ & $\mathrm{Y}$ & $\begin{array}{c}\mathrm{N} \\
\text { Asgn.1 }\end{array}$ & $\mathrm{N}$ & $\mathrm{Y}$ & $\mathrm{Y}$ & $\begin{array}{c}\mathrm{Y} \\
\text { Asgn.3 }\end{array}$ & $\mathrm{N}$ & $\mathrm{N}$ & $\mathrm{N}$ \\
\hline Activity & $\mathrm{R} / \mathrm{P}$ & $\mathrm{R} / \mathrm{P}$ & $\mathrm{P}$ & $\mathrm{R} / \mathrm{P}$ & $\mathrm{P}$ & $\mathrm{P}$ & A & $\mathrm{R} / \mathrm{P}$ & $\mathrm{P}$ & $\mathrm{R}$ \\
\hline $\mathrm{F}$ & $5(22)$ & $11(16)$ & $3.2(15)$ & $2(14)$ & $4.1(8)$ & $10.3(7)$ & $1(6)$ & $10(6)$ & $4.2(5)$ & $3.1(1)$ \\
\hline $\begin{array}{c}\text { Journal } \\
\text { Entry }\end{array}$ & $\mathrm{N}$ & $\mathrm{N}$ & $\mathrm{Y}$ & $\mathrm{Y}$ & $\begin{array}{c}\mathrm{Y} \\
\text { Asgn.1 }\end{array}$ & $\begin{array}{c}\mathrm{Y} \\
\text { Asgn.3 } \\
\end{array}$ & $\mathrm{N}$ & $\mathrm{Y}$ & $\begin{array}{c}\mathrm{N} \\
\text { Asgn.1 }\end{array}$ & $\mathrm{N}$ \\
\hline Activity & $\mathrm{R} / \mathrm{P}$ & $\mathrm{R} / \mathrm{P}$ & $\mathrm{R} / \mathrm{P}$ & $\mathrm{P}$ & $\mathrm{R} / \mathrm{P}$ & A & $\mathrm{P}$ & $\mathrm{P}$ & $\mathrm{P}$ & $\mathrm{R}$ \\
\hline $\mathrm{G}$ & $3.2(21)$ & $4.2(19)$ & $10.3(17)$ & $5(14)$ & $10(8)$ & $4.1(7)$ & $3.1(4)$ & 11(4) & 1(3) & $2(2)$ \\
\hline $\begin{array}{c}\text { Journal } \\
\text { Entry }\end{array}$ & $\mathrm{Y}$ & $\begin{array}{c}\mathrm{N} \\
\text { Asgn. } 1\end{array}$ & $\begin{array}{c}\mathrm{Y} \\
\text { Asgn.3 }\end{array}$ & $\mathrm{N}$ & $\mathrm{Y}$ & $\begin{array}{c}\mathrm{Y} \\
\text { Asgn.1 }\end{array}$ & $\mathrm{N}$ & $\mathrm{N}$ & $\mathrm{N}$ & $\mathrm{Y}$ \\
\hline Activity & $\mathrm{R} / \mathrm{P}$ & $\mathrm{P}$ & A & $\mathrm{R} / \mathrm{P}$ & $\mathrm{P}$ & $\mathrm{R} / \mathrm{P}$ & $\mathrm{R}$ & $\mathrm{R} / \mathrm{P}$ & $\mathrm{P}$ & $\mathrm{P}$ \\
\hline $\mathrm{H}$ & $5(18)$ & $4.1(16)$ & $3.2(12)$ & $10.3(12)$ & $4.2(11)$ & $11(10)$ & $2(9)$ & $10(9)$ & 1(3) & $3.1(1)$ \\
\hline $\begin{array}{c}\text { Journal } \\
\text { Entry } \\
\end{array}$ & $\mathrm{N}$ & $\begin{array}{c}\mathrm{Y} \\
\text { Asgn.1 }\end{array}$ & $\mathrm{Y}$ & $\begin{array}{c}\mathrm{Y} \\
\text { Asgn.3 } \\
\end{array}$ & $\begin{array}{c}\mathrm{N} \\
\text { Asgn.1 }\end{array}$ & $\mathrm{N}$ & $\mathrm{Y}$ & $\mathrm{Y}$ & $\mathrm{N}$ & $\mathrm{N}$ \\
\hline Activity & $\mathrm{R} / \mathrm{P}$ & $\mathrm{R} / \mathrm{P}$ & $\mathrm{R} / \mathrm{P}$ & A & $\mathrm{P}$ & $\mathrm{R} / \mathrm{P}$ & $\mathrm{P}$ & $\mathrm{P}$ & $\mathrm{P}$ & $\mathrm{R}$ \\
\hline I & $4.1(32)$ & $10(20)$ & $3.2(18)$ & $5(10)$ & 11(9) & $4.2(4)$ & $2(3)$ & $10.3(3)$ & $1(1)$ & $3.1(0)$ \\
\hline $\begin{array}{c}\text { Journal } \\
\text { Entry }\end{array}$ & $\begin{array}{c}\mathrm{Y} \\
\text { Asgn.1 }\end{array}$ & $\mathrm{Y}$ & $\mathrm{Y}$ & $\mathrm{N}$ & $\mathrm{N}$ & $\begin{array}{c}\mathrm{N} \\
\text { Asgn.1 }\end{array}$ & $\mathrm{Y}$ & $\begin{array}{c}\mathrm{Y} \\
\text { Asgn.3 }\end{array}$ & $\mathrm{N}$ & $\mathrm{N}$ \\
\hline Activity & $\mathrm{R} / \mathrm{P}$ & $\mathrm{P}$ & $\mathrm{R} / \mathrm{P}$ & $\mathrm{R} / \mathrm{P}$ & $\mathrm{R} / \mathrm{P}$ & $\mathrm{P}$ & $\mathrm{P}$ & A & $\mathrm{P}$ & $\mathrm{R}$ \\
\hline $\mathrm{J}$ & $3.2(23)$ & $11(18)$ & $5(17)$ & $10(15)$ & $4.1(10)$ & $10.3(9)$ & $2(3)$ & $1(2)$ & $3.1(1)$ & $4.2(1)$ \\
\hline $\begin{array}{c}\text { Journal } \\
\text { Entry }\end{array}$ & $\mathrm{Y}$ & $\mathrm{N}$ & $\mathrm{N}$ & $\mathrm{Y}$ & $\begin{array}{c}\mathrm{Y} \\
\text { Asgn.1 }\end{array}$ & $\begin{array}{c}\mathrm{Y} \\
\text { Asgn.3 }\end{array}$ & $\mathrm{Y}$ & $\mathrm{N}$ & $\mathrm{N}$ & $\begin{array}{c}\mathrm{N} \\
\text { Asgn.1 }\end{array}$ \\
\hline Activity & $\mathrm{R} / \mathrm{P}$ & $\mathrm{R} / \mathrm{P}$ & $\mathrm{R} / \mathrm{P}$ & $\mathrm{P}$ & $\mathrm{R} / \mathrm{P}$ & $\mathrm{A}$ & $\mathrm{P}$ & $\mathrm{P}$ & $\mathrm{R}$ & $\mathrm{P}$ \\
\hline
\end{tabular}

TABLE KEY:

$\mathrm{Y}=\mathrm{Yes} ; \mathrm{N}=\mathrm{No}$

$\mathrm{P}=$ Peer Interaction reflecting on personal experience (e.g., a time when I "wronged" someone)

$\mathrm{R}=$ Peer Interaction reflecting on a reading (e.g., complete instant inventory survey)

$\mathrm{R} / \mathrm{P}=$ Peer Interaction reflecting on a reading and personal experience

$\mathrm{A}=$ Peer Interaction based on an academic activity (e.g., classroom observation) 
Table $1 \mathrm{~b}$

\begin{tabular}{|c|c|c|c|c|c|c|c|c|c|c|}
\hline Subject & \multicolumn{10}{|c|}{ Peer Interactions from most active to least (with amount of each student's interactions) } \\
\hline A & $3.2(9)$ & $11(8)$ & $4.2(3)$ & $2(2)$ & $10.3(2)$ & $1(1)$ & $3.1(1)$ & $4.1(1)$ & $5(1)$ & $10(1)$ \\
\hline $\begin{array}{c}\text { Journal } \\
\text { Entry }\end{array}$ & Y & $\mathrm{N}$ & $\begin{array}{c}\mathrm{N} \\
\text { Asgn.1 }\end{array}$ & $\mathrm{Y}$ & $\begin{array}{c}\mathrm{Y} \\
\text { Asgn.3 }\end{array}$ & $\mathrm{N}$ & $\mathrm{N}$ & $\begin{array}{c}\mathrm{Y} \\
\text { Asgn.1 }\end{array}$ & $\mathrm{N}$ & $\mathrm{Y}$ \\
\hline Activity & $\mathrm{R} / \mathrm{P}$ & $\mathrm{R} / \mathrm{P}$ & $\mathrm{P}$ & $\mathrm{P}$ & A & $\mathrm{P}$ & $\mathrm{R}$ & $\mathrm{R} / \mathrm{P}$ & $\mathrm{R} / \mathrm{P}$ & $\mathrm{P}$ \\
\hline $\mathrm{B}$ & $5(14)$ & $11(14)$ & $4.1(10)$ & $10(10)$ & $3.2(9)$ & $4.2(8)$ & $2(7)$ & $3.1(6)$ & 1(4) & $10.3(1)$ \\
\hline $\begin{array}{c}\text { Journal } \\
\text { Entry }\end{array}$ & $\mathrm{N}$ & $\mathrm{N}$ & $\begin{array}{c}\mathrm{Y} \\
\text { Asgn.1 }\end{array}$ & $\mathrm{Y}$ & $\bar{Y}$ & $\begin{array}{c}\mathrm{N} \\
\text { Asgn.1 }\end{array}$ & $\mathrm{Y}$ & $\mathrm{N}$ & $\mathrm{N}$ & $\begin{array}{c}\mathrm{Y} \\
\text { Asgn.3 }\end{array}$ \\
\hline Activity & $\mathrm{R} / \mathrm{P}$ & $\mathrm{R} / \mathrm{P}$ & $\mathrm{R} / \mathrm{P}$ & $\mathrm{P}$ & $\mathrm{R} / \mathrm{P}$ & $\mathrm{P}$ & $\mathrm{P}$ & $\mathrm{R}$ & $\mathrm{P}$ & A \\
\hline $\mathrm{C}$ & $3.1(6)$ & $4.1(5)$ & $3.2(4)$ & $11(4)$ & $5(3)$ & $1(2)$ & $2(2)$ & $4.2(2)$ & $10(2)$ & $10.3(2)$ \\
\hline $\begin{array}{l}\text { Journal } \\
\text { Entry }\end{array}$ & $\mathrm{N}$ & $\begin{array}{c}\mathrm{Y} \\
\text { Asgn.1 }\end{array}$ & $\mathrm{Y}$ & $\mathrm{N}$ & $\mathrm{N}$ & $\mathrm{N}$ & $\mathrm{Y}$ & $\begin{array}{c}\mathrm{N} \\
\text { Asgn.1 }\end{array}$ & $\mathrm{Y}$ & $\begin{array}{c}\mathrm{Y} \\
\text { Asgn.3 } \\
\end{array}$ \\
\hline Activity & $\mathrm{R}$ & $\mathrm{R} / \mathrm{P}$ & $\mathrm{R} / \mathrm{P}$ & $\mathrm{R} / \mathrm{P}$ & $\mathrm{R} / \mathrm{P}$ & $\mathrm{P}$ & $\mathrm{P}$ & $\mathrm{P}$ & $\mathrm{P}$ & A \\
\hline $\mathrm{D}$ & $5(4)$ & $4.1(3)$ & $3.2(2)$ & $4.2(2)$ & $10.3(2)$ & $10(1)$ & $11(1)$ & $1(0)$ & $2(0)$ & $3.1(0)$ \\
\hline $\begin{array}{l}\text { Journal } \\
\text { Entry }\end{array}$ & $\mathrm{N}$ & $\begin{array}{c}\mathrm{Y} \\
\text { Asgn.1 }\end{array}$ & $\mathrm{Y}$ & $\begin{array}{c}\mathrm{N} \\
\text { Asgn.1 }\end{array}$ & $\begin{array}{c}\mathrm{Y} \\
\text { Asgn.3 }\end{array}$ & $\mathrm{Y}$ & $\mathrm{N}$ & $\mathrm{N}$ & $\mathrm{Y}$ & $\mathrm{N}$ \\
\hline Activity & $\mathrm{R} / \mathrm{P}$ & $\mathrm{R} / \mathrm{P}$ & $\mathrm{R} / \mathrm{P}$ & $\mathrm{P}$ & A & $\mathrm{P}$ & $\mathrm{R} / \mathrm{P}$ & $\mathrm{P}$ & $\mathrm{P}$ & $\mathrm{R}$ \\
\hline $\mathrm{E}$ & $4.1(6)$ & $5(6)$ & $3.2(3)$ & $4.2(3)$ & $10(2)$ & $10.3(2)$ & $2(1)$ & $1(0)$ & $3.1(0)$ & $11(0)$ \\
\hline $\begin{array}{l}\text { Journal } \\
\text { Entry }\end{array}$ & $\begin{array}{c}\mathrm{Y} \\
\text { Asgn.1 }\end{array}$ & $\mathrm{N}$ & $\mathrm{Y}$ & $\begin{array}{c}\mathrm{N} \\
\text { Asgn. } 1\end{array}$ & $\mathrm{Y}$ & $\begin{array}{c}\mathrm{Y} \\
\text { Asgn.3 }\end{array}$ & $\mathrm{Y}$ & $\mathrm{N}$ & $\mathrm{N}$ & $\mathrm{N}$ \\
\hline Activity & $\mathrm{R} / \mathrm{P}$ & $\mathrm{R} / \mathrm{P}$ & $\mathrm{R} / \mathrm{P}$ & $\mathrm{P}$ & $\mathrm{P}$ & A & $\mathrm{P}$ & $\mathrm{P}$ & $\mathrm{R}$ & $\mathrm{R} / \mathrm{P}$ \\
\hline $\mathrm{F}$ & $3.2(8)$ & $2(6)$ & $5(3)$ & $10(2)$ & $4.2(1)$ & $10.3(1)$ & $1(0)$ & $3.1(0)$ & $4.1(0)$ & $11(0)$ \\
\hline $\begin{array}{c}\text { Journal } \\
\text { Entry }\end{array}$ & $\mathrm{Y}$ & $\mathrm{Y}$ & $\mathrm{N}$ & $\mathrm{Y}$ & $\begin{array}{c}\mathrm{N} \\
\text { Asgn.1 } \\
\end{array}$ & $\begin{array}{c}\mathrm{Y} \\
\text { Asgn.3 } \\
\end{array}$ & $\mathrm{N}$ & $\mathrm{N}$ & $\begin{array}{c}\text { Y } \\
\text { Asgn.1 }\end{array}$ & $\mathrm{N}$ \\
\hline Activity & $\mathrm{R} / \mathrm{P}$ & $\mathrm{P}$ & $\mathrm{R} / \mathrm{P}$ & $\mathrm{P}$ & $\mathrm{P}$ & A & $\mathrm{P}$ & $\mathrm{R}$ & $\mathrm{R} / \mathrm{P}$ & $\mathrm{R} / \mathrm{P}$ \\
\hline $\mathrm{G}$ & $10.3(6)$ & $4.2(5)$ & $3.2(4)$ & $4.1(3)$ & 11(2) & $3.1(1)$ & $5(1)$ & $1(0)$ & $2(0)$ & $10(0)$ \\
\hline $\begin{array}{l}\text { Journal } \\
\text { Entry. }\end{array}$ & $\begin{array}{c}\mathrm{Y} \\
\text { Asgn.3 }\end{array}$ & $\begin{array}{c}\mathrm{N} \\
\text { Asgn.1 }\end{array}$ & $\mathrm{Y}$ & $\begin{array}{c}\mathrm{Y} \\
\text { Asgn.1 }\end{array}$ & $\mathrm{N}$ & $\mathrm{N}$ & $\mathrm{N}$ & $\mathrm{N}$ & $\mathrm{Y}$ & $\mathrm{Y}$ \\
\hline Activity & A & $\mathrm{P}$ & $\mathrm{R} / \mathrm{P}$ & $\mathrm{R} / \mathrm{P}$ & $\mathrm{R} / \mathrm{P}$ & $\mathrm{R}$ & $\mathrm{R} / \mathrm{P}$ & $\mathrm{P}$ & $\mathrm{P}$ & $\mathrm{P}$ \\
\hline $\mathrm{H}$ & $4.1(12)$ & $5(6)$ & $10.3(6)$ & $3.2(5)$ & $2(4)$ & $11(3)$ & $4.2(1)$ & $10(1)$ & $1(0)$ & $3.1(0)$ \\
\hline $\begin{array}{l}\text { Journal } \\
\text { Entry }\end{array}$ & $\begin{array}{c}\mathrm{Y} \\
\text { Asgn.1 } \\
\end{array}$ & $\mathrm{N}$ & $\begin{array}{c}\mathrm{Y} \\
\text { Asgn.3 } \\
\end{array}$ & $\mathrm{Y}$ & $\mathrm{Y}$ & $\mathrm{N}$ & $\begin{array}{c}\mathrm{N} \\
\text { Asgn.1 }\end{array}$ & $\mathrm{Y}$ & $\mathrm{N}$ & $\mathrm{N}$ \\
\hline Activity & $\mathrm{R} / \mathrm{P}$ & $\mathrm{R} / \mathrm{P}$ & $\mathrm{A}$ & $\mathrm{R} / \mathrm{P}$ & $\mathrm{P}$ & $\mathrm{R} / \mathrm{P}$ & $\mathrm{P}$ & $\mathrm{P}$ & $\mathrm{P}$ & $\mathrm{R}$ \\
\hline I & $4.1(8)$ & $10(7)$ & $5(5)$ & $3.2(4)$ & $4.2(1)$ & $1(0)$ & $2(0)$ & $3.1(0)$ & $10.3(0)$ & $11(0)$ \\
\hline $\begin{array}{l}\text { Journal } \\
\text { Entry }\end{array}$ & $\begin{array}{c}\mathrm{Y} \\
\text { Asgn.1 }\end{array}$ & $\mathrm{Y}$ & $\mathrm{N}$ & $\mathrm{Y}$ & $\begin{array}{c}\mathrm{N} \\
\text { Asgn.1 }\end{array}$ & $\mathrm{N}$ & $\mathrm{Y}$ & $\mathrm{N}$ & $\begin{array}{c}\mathrm{Y} \\
\text { Asgn.3 }\end{array}$ & $\mathrm{N}$ \\
\hline Activity & $\mathrm{R} / \mathrm{P}$ & $\mathrm{P}$ & $\mathrm{R} / \mathrm{P}$ & $\mathrm{R} / \mathrm{P}$ & $\mathrm{P}$ & $\mathrm{P}$ & $\mathrm{P}$ & $\mathrm{R}$ & $\mathrm{A}$ & $\mathrm{R} / \mathrm{P}$ \\
\hline $\mathrm{J}$ & $5(6)$ & $4.1(5)$ & $3.2(3)$ & $10(1)$ & $1(0)$ & $2(0)$ & $3.1(0)$ & $4.2(0)$ & $10.3(0)$ & $11(0)$ \\
\hline $\begin{array}{l}\text { Journal } \\
\text { Entry }\end{array}$ & $\mathrm{N}$ & $\begin{array}{c}\mathrm{Y} \\
\text { Asgn.1 }\end{array}$ & $\mathrm{Y}$ & $\mathrm{Y}$ & $\mathrm{N}$ & $\mathrm{Y}$ & $\mathrm{N}$ & $\begin{array}{c}\mathrm{N} \\
\text { Asgn.1 }\end{array}$ & $\begin{array}{c}\mathrm{Y} \\
\text { Asgn.3 }\end{array}$ & $\mathrm{N}$ \\
\hline Activity & $\mathrm{R} / \mathrm{P}$ & $\mathrm{R} / \mathrm{P}$ & $\mathrm{R} / \mathrm{P}$ & $\mathrm{P}$ & $\mathrm{P}$ & $\mathrm{P}$ & $\mathrm{R}$ & $\mathrm{P}$ & $\mathrm{A}$ & $\mathrm{R} / \mathrm{P}$ \\
\hline
\end{tabular}

TABLE KEY:

$\mathrm{Y}=\mathrm{Yes} ; \mathrm{N}=\mathrm{No}$

$\mathrm{P}=$ Peer Interaction reflecting on personal experience (e.g., a time when I "wronged" someone)

$\mathrm{R}=$ Peer Interaction reflecting on a reading (e.g., complete instant inventory survey)

$\mathrm{R} / \mathrm{P}=$ Peer Interaction reflecting on a reading and personal experience

$\mathrm{A}=$ Peer Interaction based on an academic activity (e.g., classroom observation) 
A comparison of peer responses shows that subjects interacted more with their peers than vice-versa. On average, subjects responded twice as often as did their peers. For instance, in exchanges throughout the course, subject A posted 21 responses to classmates, while classmates only responded 8 times to subject A (see Tables $2 \mathrm{a}, 2 \mathrm{~b}$ and 2c). This suggests that minimal recognition by peers can generate substantial interaction.

Table 2a

\begin{tabular}{|c|c|c|c|c|}
\hline \multicolumn{5}{|l|}{ Peer Interaction Quantities } \\
$\begin{array}{c}\text { Study } \\
\text { Subject }\end{array}$ & Word Count & $\begin{array}{l}\text { Peers responding to } \\
\text { study-subject }\end{array}$ & $\begin{array}{l}\text { Study-subject } \\
\text { responding to peers }\end{array}$ & Total interactions \\
\hline A & 3448 & 8 & 21 & 29 \\
\hline B & 7739 & 22 & 61 & 83 \\
\hline C & 4050 & 18 & 14 & 32 \\
\hline D & 2586 & 8 & 7 & 15 \\
\hline E & 3434 & 11 & 12 & 23 \\
\hline F & 4131 & 6 & 15 & 21 \\
\hline G & 4547 & 1 & 21 & 22 \\
\hline H & 4155 & 15 & 23 & 38 \\
\hline I & 5660 & 6 & 19 & 25 \\
\hline J & 2999 & 7 & 8 & 15 \\
\hline
\end{tabular}

Table $2 b$

\begin{tabular}{|c|c|c|c|}
\hline \multicolumn{4}{|c|}{ Peer Interaction Quantities (each category arranged from lowest to highest) ${ }^{1}$} \\
\hline Word Count & $\begin{array}{l}\text { Peers responding to } \\
\text { study-subjects }\end{array}$ & $\begin{array}{l}\text { Study- subjects } \\
\text { responding to peers }\end{array}$ & Total interactions \\
\hline 2586 & 1 & 7 & 15 \\
\hline 2999 & 6 & 8 & 15 \\
\hline 3434 & 6 & 12 & 21 \\
\hline 3448 & 7 & 14 & 22 \\
\hline 4050 & 8 & 15 & 23 \\
\hline 4131 & 8 & 19 & 25 \\
\hline 4155 & 11 & 21 & 29 \\
\hline 4547 & 15 & 21 & 32 \\
\hline 5660 & 18 & 23 & 38 \\
\hline 7739 & 22 & 61 & 83 \\
\hline Average: 4275 & Average: 10 & Average: 20 & Average: 30 \\
\hline
\end{tabular}


Table 2c: Number of interactions (note: “--” means subject posted but did not interact)

\begin{tabular}{|l|c|c|c|c|c|c|c|c|c|c|c|}
\hline Subject & A & B & C & D & E & F & G & H & I & J & Totals \\
\hline $\begin{array}{l}\text { Total } \\
\text { Interactions }\end{array}$ & 29 & 83 & 32 & 15 & 23 & 21 & 22 & 38 & 25 & 15 & 303 \\
\hline Wk 1 & 1 & 4 & 2 & -- & -- & -- & -- & -- & -- & -- & 7 \\
\hline Wk 2 & 2 & 7 & 2 & -- & 1 & 6 & -- & 4 & -- & -- & 22 \\
\hline Wk 3.1 & 1 & 6 & 6 & -- & -- & -- & 1 & -- & -- & -- & 14 \\
\hline Wk 3.2 & 9 & 9 & 4 & 2 & 3 & 8 & 4 & 5 & 4 & 3 & 51 \\
\hline Wk 4.1 & 1 & 10 & 5 & 3 & 6 & -- & 3 & 12 & 8 & 5 & 53 \\
\hline Wk 4.2 & 3 & 8 & 2 & 2 & 3 & 1 & 5 & 1 & 1 & -- & 26 \\
\hline $\begin{array}{l}\text { Wk 5 } \\
\text { Whe amount of interactions is based on number of times all other peers respond to a }\end{array}$ \\
\hline $\begin{array}{l}\text { Wk 10 } \\
\text { subject's initial post, as well as the number of times a subject responds to all others. }\end{array}$ \\
\hline \begin{tabular}{l} 
Wk10.3 \\
\hline
\end{tabular}
\end{tabular}

It was interesting to note the low occurrence of the language-game Reporting, characterized by a tone of aloofness which points to the high level of interaction in the course given that the tone of the other language-games encouraged peer responses. Moreover, there are some correlations between language-games and demographics. Most obvious, the language-game Experienced Practitioner was expressed by the subjects who were teachers. The language-game Recapitulation was most often expressed by subjects who had more life experience, such as a senior teacher or a mature student. The language-game Peer Engagement was absent from the locutions of subjects who were the younger undergrads and new teachers; similarly, Peer Acknowledgement played a small part in the interactions of these same subjects (see Tables 3 and 4). 
Table 3: Type of Language Games (based on word count)

\begin{tabular}{|c|c|c|c|c|c|c|c|c|c|c|}
\hline Subject & $\begin{array}{c}\mathrm{A} \\
\% 1 \\
0\end{array}$ & $\begin{array}{l}\mathrm{B} \\
\% \\
\end{array}$ & $\begin{array}{l}\mathrm{C} \\
\% \\
\end{array}$ & $\begin{array}{l}\mathrm{D} \\
\% \\
\end{array}$ & $\begin{array}{c}\mathrm{E} \\
\% \\
\end{array}$ & $\begin{array}{l}\mathrm{F} \\
\% \\
\end{array}$ & $\begin{array}{l}\mathrm{G} \\
\% \\
\end{array}$ & $\begin{array}{l}\mathrm{H} \\
\% \\
\end{array}$ & $\begin{array}{c}\mathrm{I} \\
\% \\
\end{array}$ & $\begin{array}{c}\mathrm{J} \\
\% \\
\end{array}$ \\
\hline $\begin{array}{l}\text { Personal } \\
\text { Insight }\end{array}$ & 70 & 52 & 34 & 55 & 59 & 47 & 41 & 38 & 50 & 60 \\
\hline $\begin{array}{l}\text { Logical } \\
\text { Thinking } \\
\text { Through }\end{array}$ & 6 & 2 & 49 & 18 & 15 & 20 & 30 & 12 & 6 & 5 \\
\hline Reporting & 0 & 1 & 11 & 20 & 12 & 8 & 7 & 15 & 13 & 14 \\
\hline $\begin{array}{l}\text { Peer } \\
\text { Acknow- } \\
\text { ledgement }\end{array}$ & 12 & 20 & 2 & 3 & 7 & 8 & 8 & 11 & 16 & 3 \\
\hline $\begin{array}{l}\text { Recapitu- } \\
\text { lation }\end{array}$ & 7 & 10 & 0 & 0 & 2 & 14 & 2 & 18 & 7 & 0 \\
\hline $\begin{array}{l}\text { Critical } \\
\text { Self- } \\
\text { awareness }\end{array}$ & 1 & 2 & 3 & 3 & 5 & 1 & 3 & 2 & 5 & 0 \\
\hline $\begin{array}{l}\text { Peer } \\
\text { Engagement }\end{array}$ & 0 & 4 & 0 & 0 & 0 & 2 & 2 & 4 & 2 & 0 \\
\hline Utility & 2 & 1 & 1 & 1 & 0 & 0 & 1 & 0 & 0 & 0 \\
\hline $\begin{array}{l}\text { Experienced } \\
\text { Practitioner }\end{array}$ & 2 & 9 & 0 & 0 & 0 & 0 & 1 & 0 & 0 & 18 \\
\hline
\end{tabular}

\begin{tabular}{|c|l|}
\hline \multicolumn{2}{|l|}{ BACKGROUND OF SUBJECTS } \\
\hline Subject A & a recent PDP graduate who had just been hired as a Teacher On Call \\
\hline Subject B & a senior teacher at the end of her career \\
\hline Subjects C, D \& E & three undergrad students wanting to apply to PDP \\
\hline Subjects F, G, H \& I & $\begin{array}{l}\text { four mature students who took time off to raise a family and now } \\
\text { sought to complete their undergrad degrees }\end{array}$ \\
\hline Subject J & a junior teacher who had been working for a few years \\
\hline
\end{tabular}


Table 4: Word Count by week (broken down by subject)

\begin{tabular}{|l|c|c|c|c|c|c|c|c|c|c|c|}
\hline Subject & A & B & C & D & E & F & G & H & I & J & Avg. \\
\hline & & & & & & & & & & & \\
\hline $\begin{array}{l}\text { Total word } \\
\text { count }\end{array}$ & 3448 & 7739 & 4050 & 2586 & 3434 & 4131 & 4547 & 4155 & 5660 & 2999 & 4275 \\
\hline & & & & & & & & & & & \\
\hline Wk 1 (\%) & 3 & 3 & 2 & 2 & 2 & 6 & 3 & 3 & 1 & 2 & 3 \\
\hline Wk 2 (\%) & 6 & 13 & 10 & 8 & 9 & 14 & 2 & 9 & 3 & 3 & 8 \\
\hline Wk 3.1 (\%) & 3 & 4 & 7 & 1 & 1 & 1 & 4 & 1 & 0 & 1 & 2 \\
\hline Wk 3.2 (\%) & 25 & 10 & 11 & 14 & 16 & 15 & 21 & 12 & 18 & 23 & 17 \\
\hline Wk 4.1 (\%) & 10 & 15 & 13 & 10 & 18 & 8 & 7 & 16 & 32 & 10 & 14 \\
\hline Wk 4.2 (\%) & 13 & 14 & 11 & 11 & 15 & 5 & 19 & 11 & 4 & 1 & 10 \\
\hline Wk 5 (\%) & 10 & 16 & 8 & 14 & 14 & 22 & 14 & 18 & 10 & 17 & 14 \\
\hline \begin{tabular}{l} 
Wk 10 (\%) \\
\hline
\end{tabular} & 8 & 10 & 13 & 11 & 14 & 6 & 8 & 9 & 20 & 15 & 11 \\
\hline \begin{tabular}{l} 
Wk10.3(\%) \\
\hline
\end{tabular} & 4 & 3 & 12 & 13 & 7 & 7 & 17 & 12 & 3 & 9 & 9 \\
\hline $\begin{array}{l}\text { Wk 11 (\%) } \\
\text { Total word count for the course }\end{array}$ & 18 & 12 & 14 & 17 & 4 & 16 & 4 & 10 & 9 & 18 & 12 \\
\hline
\end{tabular}

\begin{tabular}{|c|l|}
\hline BACKGROUND OF SUBJECTS \\
\hline Subject A & a recent PDP graduate who had just been hired as a Teacher On Call \\
\hline Subject B & a senior teacher at the end of her career \\
\hline Subjects C, D \& E & three undergrad students wanting to apply to PDP \\
\hline Subjects F, G, H \& I & $\begin{array}{l}\text { four mature students who took time off to raise a family and now } \\
\text { sought to complete their undergrad degrees }\end{array}$ \\
\hline Subject J & a junior teacher who had been working for a few years \\
\hline
\end{tabular}


The language-game Critical Self-Awareness accounted for two percent of the word count and participation of twenty times. Its most common occurrence was during week four, and its highest level of participation was six out of ten subjects, which occurred in task two of week four. Moreover, no clear demographic link was found nor any correlation to increases in assignment clarification by the Tutor Marker. In three of the four peer interaction activities where Critical Self-Awareness appeared most often, interactions drew on readings and personal experience. It's interesting to note that Critical Self-Awareness had the highest participation in week four, task two, which did not make explicit reference to readings. There was something unique, however, about the instructions of this peer interaction task; subjects were asked to "respond" to five "school words": schedule, punctuality, order, rules, and supervision. This task differed from other peer interactions in that it seemed to request 'gut' responses to 'trigger' words. In comparison, the instructions of other peer interactions requested narratives and exploratory, reflective, contributions. Yet, task one of week four was reflective. Perhaps, it was the combined tasks of this week that generated the strongest occurrence of Critical Self-Awareness? Week four accounted for forty percent of this languagegame's word count; the second highest week only had a quarter of this word count.

Of the twenty-five identified occurrences of Critical Self-Awareness, three-quarters occurred as responses to peers. In addition, in all the cases, including the few times when it formed part of a subject's main posting, Critical Self-Awareness was expressed in the context of other language-games. For example, the following is a response to a peer:

[1] Hi again, Without re-reading all the posts, I think you were the only one that came up with two types of order...[2] I hadn't even though about it in terms of sequencing :) [3] But I also see a common thread throughout the posts with some of the words having a harsh connotation, such as when you say "authoritative" for rules and order... (subject G, week 4, task two)

The above passage contains three language-games, each identified by a number in square brackets. The first [1] is Peer Acknowledgement, the second [2] is Critical SelfAwareness, and the third [3] is Logically Thinking Through. Given that in all the occurrences of Critical Self-Awareness this language-game never appeared as a stand alone statement, suggests that in the interactions it needed to be supported by other thought processes (e.g., recognition of others, critical thinking).

Another notable finding concerns the language game Utility. While only accounting for a very small aspect of the peer interaction assignments, most student inquiries about assignment clarification occur in a different location of the website referred to as the Tutor Marker Office. For the period of this study, from fall 2009 to fall 2010, student inquiries fell from 256 to 106, respectively. This paralleled an increase in instructions to students by the course's Tutor Marker, who started with the course in fall 2009, providing spotty instructions, and by fall 2010 was posting seventeen instructions consisting of almost five thousands words. This suggests that greater Tutor Marker involvement and course knowledge can greatly reduce uncertainty by students. 


\section{Conclusion}

The principal focus of this investigation was to identify occurrences of 'meaningful participation' by finding evidence of engagement (i.e., reflexivity). Based on word count and participation, the highest occurring language-games were Personal Insight, Peer Acknowledgement and Logically Thinking Through. The locutionary intentions of these language-games were inclusivity, sincerity and inquiry. This would suggest that the course was successful in making the work personally relevant in that students were comfortable in expressing their own opinions and ideas. They were not simply regurgitating "lecture" or "text book" ideas. We recognized the limitations of a qualitative factor such as number of words. However, the number of words spoken is often an indicator of locus of control. Students did appear to feel in control of the situation. We found that the highest level of activity were interactions that drew on readings and personal experience. This seemed to be the comfort zone for most students, where they felt they had something to say that was, perhaps, acceptable. We were reminded that teaching and learning contain intimate human actions and reactions and a delicate awareness is required in moving through the narrative that such actions and reactions create.

\section{What Next?}

I felt reassured by this analysis. The peer interactions were working in much the way I had intended. There was less elocutions of critical self- awareness than one might expect. I realized that I had put a lot of energy into making the students feel strong and good about themselves. This might have been a bit of a disservice. Did I not trust them enough to be able to be critical of themselves?

I re-examined the work on learning styles and Jungian archetypes and decided that curriculum material might provide an opportunity for students to examine both strengths and areas of personal challenge. Critical awareness can be transformative when students are given ample support. That is a challenge. Time. Mentorship. Again, I decided to use peer interaction as a strategy. I would incorporate grouping into the course study guide, inviting students with similar strengths and similar weaknesses to discuss how these were manifest and to share strategies for coping with potential mishap and with correcting unintentional bad habits. It was my hope that this method of mutual sharing and open dialogue would be supportive and instructive.

Before I could expect students to take such risks, I would have to ensure the environment was feeling safe and participants could trust one another to neither attack nor expose any member of the class. Though a challenge, it was also an opportunity to teach the importance of safety and to mentor students in creating such a space.

The analysis of the aspects of the course that most supported peer interaction that was meaningful suggested using a combination of reading and personal experience. That prompted me to create assignments that invited personal reflection and outside reading with a focus on creating a safe environment for risk taking. Once again, I invented the 
tasks and then looked for readings that matched the task and contained the theoretical constructs that supported the ideas inherent in the task.

Designing a course is a complex task, moving from a place of lived experience, reflection, trusting one's instincts, selecting the essential components, deciding on a developmental design, scaffolding assignments, creating experiential exercises, allowing for practice and mastery, finding readings that are relevant and instructive. The creation, the reflection, the literature review, the research and redesign take time. In the case of this course, five years worth of time.

It is not the intention of this article to give precise instruction in how to design an online course. It is, however, the hope of its authors, that you might be willing to try to move away from text driven courses to more interactive courses. It is also the hope that this method of analyzing peer interactions might be of some value to you.

The authors invite any responses and ideas. Please drop us a line at Mamchur@sfu.ca so we can enjoy continuing the dialogue together.

\section{References}

Austin, J. L. (1962). How to do things with words. Cambridge: Harvard University Press.

Bound, Helen (2010). Developing Quality Online Dialogue: Dialogical Inquiry. International Journal of Teaching and Learning in Higher Education, v22 n2 p107-124 2010. Retrieved from ERIC (EJ930136).

Buber, M. (2000). I and Thou. New York: Scribner Classics.

Dennen, Vanessa Paz; Wieland, Kristina (2007). From Interaction to Intersubjectivity: Facilitating Online Group Discourse Processes. Distance Education, v28 n3 p281-297 Nov 2007. Retrieved from ERIC (EJ777848).

Fisher, Mercedes; Thompson, Gregory S.; Silverberg, David A. (2005). Effective Group Dynamics in E-Learning: Case Study. Journal of Educational Technology Systems, v33 n3 p205-222, 2004-2005. Retrieved from ERIC (EJ690958).

Lowerison, Gretchen, Jennifer Sclater, Richard F. Schmid, and Philip C. Abrami (2006). Are We Using technology For Learning? J. Educational Technology Systems, Concordia University, Montreal, Vol. 34(4) 401-425, 2005-2006. Retrieved from EBSCO (EJ757131).

Merleau-Ponty, Maurice (1962). Phenomenology of Perception. Translated from the French by Colin Smith. New York : Humanities Press.

Merleau-Ponty, Maurice (1968). The Visible and the Invisible. Ed. by Claude Lefort, translated by Alphonso Lingis. Evanston, Ill.: Northwestern University Press. 
Paulus, Trena; Scherff, Lisa (2008). "Can Anyone Offer any Words of Encouragement?" Online Dialogue as a Support Mechanism for Preservice Teachers. Journal of Technology and Teacher Education, v16 n1 p113-136 2008. Retrieved from ERIC (EJ779021).

Rose, Mary Annette (2004). Comparing Productive Online Dialogue in Two Group Styles: Cooperative and Collaborative. American Journal of Distance Education, v18 n2 p73-88 Jun 2004. Retrieved from ERIC (EJ683301).

Sorensen, Elsebeth K.; Takle, Eugene S.; Moser, Heather M. (2006). KnowledgeBuilding Quality in Online Communities of Practice: Focusing on Learning Dialogue. Studies in Continuing Education, Routledge, v28 n3 p241-257 Nov 2006. Retrieved from ERIC (EJ753565).

Webb, Eileen; Jones, Alan; Barker, Philip; van Schaik, Paul (2004). Using E-Learning Dialogues in Higher Education. Innovations in Education and Teaching International, v41 n1 p93-103 Feb 2004. Retrieved from ERIC (EJ681646).

Wittgenstein, Ludwig (1958). Philosophical Investigations. Translated by G. E. M. Anscombe (2nd ed.). New York : Macmillan.

Zembylas, Michalinos (2008). Engaging with Issues of Cultural Diversity and Discrimination through Critical Emotional Reflexivity in Online Learning. Adult Education Quarterly: A Journal of Research and Theory, v59 n1 p61-82 2008. Retrieved from ERIC (EJ813649).

Ziegler, Mary; Paulus, Trena; Woodside, Marianne (2006). Creating a Climate of Engagement in a Blended Learning Environment. Journal of Interactive Learning Research, v17 n3 p295-318 2006. Retrieved from ERIC (EJ735738). 